ERBB2 pY1139

*PLTCSPQPEXVNQPDVRD-COOH \title{
-DTT
}
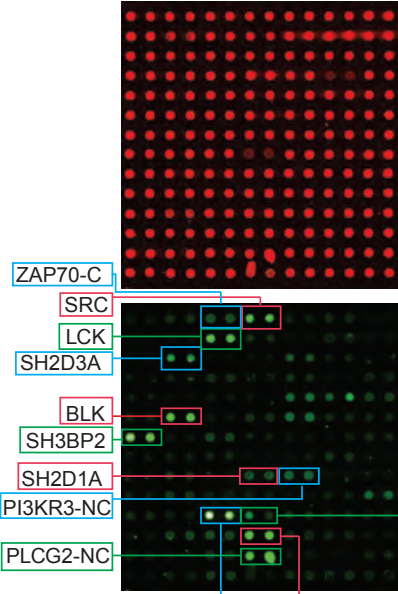

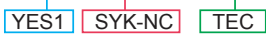

\section{ERBB2 pY803}

*QLMPXGCLLDHVD-COOH \section{-DTT}
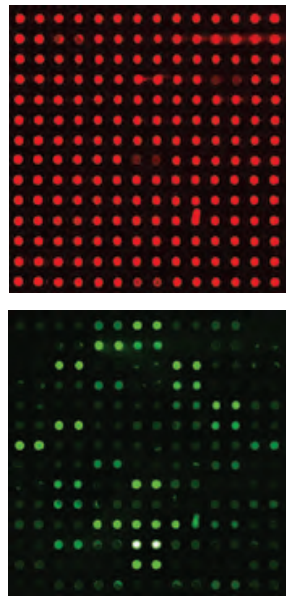

$+\mathrm{DTT}$
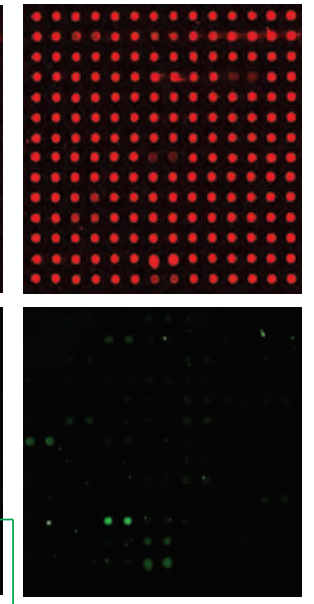

ERBB4 pY807

${ }^{*}$ CLLEXVHEHKDND-COOH -DTT
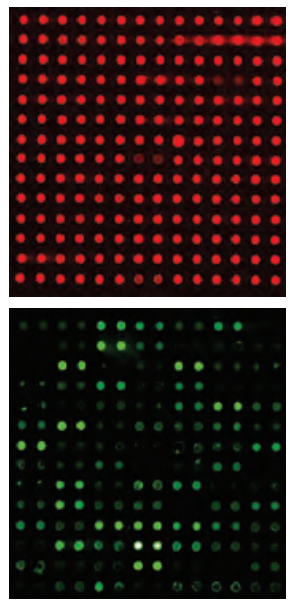

+ DTT

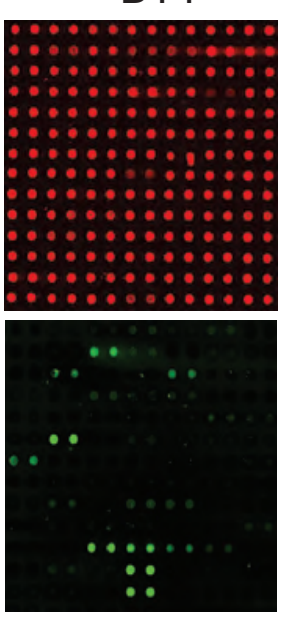

ERBB2 pY772 *LDEAXVMAGVGS-COOH
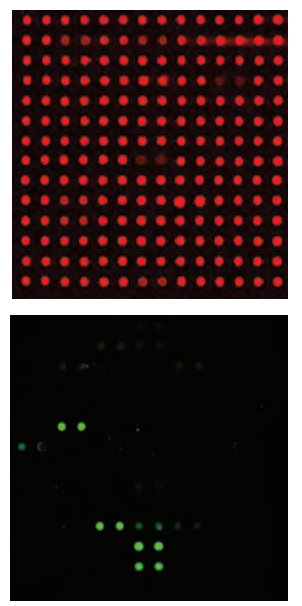
-DTT + DTT
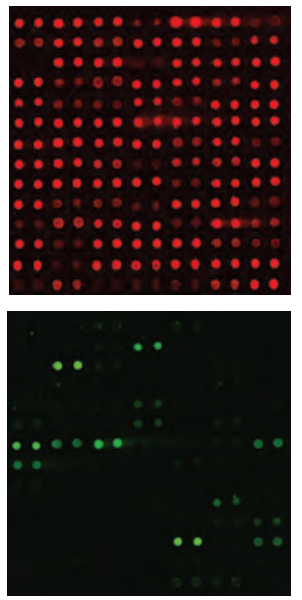